DOI: https://doi.org/10.21009/hayula.006.01.02

\title{
Leadership Education Based on the Jamaah Concept in Sayyid Qutb's Tafsir Fî Zhilâl Al-Qur'ân
}

\section{Toto Santi Aji}

Faculty of Islamic Religion, Universitas Muhammadiyah Cirebon

Email: toto.santi@umc.ac.id

\author{
Ahmad Yusron \\ Communication Science Departement, Faculty of Social and Political Sciences,, Universitas \\ Muhammadiyah Cirebon \\ Email: ahmad.yusron@umc.ac.id
}

Article Accepted: December, 09, 2021, Revised: January, 02, 2022, Approved: January 18, 2022

\begin{abstract}
Abstrak
Kontroversi yang begitu tajam di kalangan ulama berkenaan dengan konsep jamaah menjadi sisi lain yang lebih menarik lagi untuk dicari tahu jawaban kebenarannya. Penelitian ini berfokus pada upaya mengungkap konsep jamaah dari tafsir yang ditarik ke suasana kontemporer dan iklim keIndonesiaan. Metode yang digunakan dalam pembahasan penelitian ini adalah metode library research. Objek penelitian adalah tentang konsep jama'ah. Hasil penelitian ini adalah konsep pengertian Jamaah, konsep jama'ah dalam tafsir Fî Zhilâl al-Qur'ân, serta konsep jamaah sebagai satu kesatuan kepemimpinan. Kesimpulan dari penelitian ini adalah fenomena jamaah menurut Quthb tidak hanya menjadi kewajiban bagi kaum muslimin untuk meneggakkannya di dunia, akan tetapi juga sesuatu yang akan berdampak dan akan menentukan nasib seseorang di akhirat.
\end{abstract}

Kata Kunci: jamaah, kepemimpinan, Sayyid Quthb, Tafsir Fî Zhilâl Al-Qur'ân.

\begin{abstract}
The sharp controversy among the scholars regarding the jamaah (congregation) concept has become a more interesting side to finding the answer to the truth. This research focuses on uncovering the congregation concept from interpretations drawn to the contemporary atmosphere and Indonesian climate. The method employed in this research discussion was a research library. The content analysis method was a research method that utilized a set of procedures to draw valid conclusions. This study's findings included the concept of the understanding congregation, the congregation concept in Tafsir (interpretation) Fî Zhilâl al-Qur'ân, and the congregation concept as one leadership unit. This research conclusion is that the congregation phenomenon, according to Qutb, is not only an obligation for Muslims to uphold it in the world but also something that will impact and determine a person's fate in the hereafter.
\end{abstract}

Keywords: congregation, leadership, Sayyid Qutb, Tafsir fì Zhilâl Al-Qur'ân. 


\section{Introduction}

The congregation (jamaah) concept is the concept of building brotherhood, togetherness, and a community that is harmonious, peaceful, congruent, co-existing, mutually reinforcing, and complementary as a picture of an ideal and perfect society (Shawi, 2002; Aji et al., 2020). The congregation is also a system, in which there are shaf' (lines) or parts, coordination and communication path, strata of capacity, structure, functions and roles, authority and responsibility, mission, vision, and objectives, attachments and linkages, and Sharia and amaliyah, which are carried out as its work program (Quthb, 1992).

Al-Qur'an cannot be understood without the aid tool of "Tafsir Al-Qur'an" (interpretation), which will describe, explain, interpret, reveal, and elucidate from the verses' meanings in the Al-Qur'an. Terminologically, tafsir is defined by Abu Hayyan as "the science that discusses how to pronounce the Qur'anic lafadz, its instructions, its laws, both when it stands alone and when it is composed with meanings possible for it, and other things that complement it" (al-Qaththân, 1973). Meanwhile, according to Az-Zarkasyi, "tafsir is the knowledge of understanding the book of Allah revealed to the Prophet Muhammad, explaining its meanings, and issuing laws and wisdom" (al-Qaththân, 1973).

In the time of the Prophet, Al-Qur'an was interpreted by the Prophet himself, while in the time of the companions, they interpreted based on their understanding and information from the Prophet. In this context some time it is called by self-leadership (Qodriah et al., 2019). In the time of tabi'in, tafsir began to be added with information from the companions and People of the Book and their own interpretive ijtihad (al-Dzahabi, 1976). Furthermore, tafsir continued to the time of tabi'u al-tabi'in with added information from the tabi'in. At this time, tafsir began to be recorded, namely at the end of the Umayyad Dynasty and the beginning of the Abbasid Dynasty (Al-Zarkasyi, 1972). Then, it developed into modern and contemporary tafsir, namely interpretations of the current era (Shaleh, 2007). What means modern or contemporary in its era is especially contemporary interpretations.

Meanwhile, in general, both classical and contemporary types, tafsir is divided into two approaches. First, the exoteric approach is tafsir that focuses more on the dhahir side of the Al-Qur'an texts. This interpretation model is usually referred to as tafsir dhahir. Second, the esoteric approach is tafsir that concentrates more on the side of the inner (batin) signs or messages implicitly contained behind the dhahir of the Al-Qur'an texts. This interpretation kind is usually alluded to as tafsir batin or isyari (Anwar, 2010). 
Al-Qur'an as an object of interpretation (tafsir) has many aspects of study contained in it. One of the many studies of Al-Qur'an is related to the congregation concept. The congregation problem is essential in Islamic teachings. A congregation in Islam is a strong bond, which when it is destroyed, then other Islamic ties will be destroyed, namely the passivity of the law, the loss of its syi'ar, and the splitting of the people like foam in the ocean (Jabir, 1990).

Through this research, the author raises Shaykh Sayyid Qutb's views in Tafsir Fî Zhilâl Al Qur'ân regarding the congregation concept. Tafsir Fî Zhilâl Al Qur'ân itself is a type of exoteric interpretation (tafsir dhahir) and is categorized as a tafsir tahlili (analysis). It contains an ideological approach with analyzes verses that are so sharp and deep and includes aspects of thought through the ijtihad approach, as is the hermeneutic tendency, which explores directly into verse texts. However, in Tafsir Fî Zhilâl Al Qur'ân, there is also a little nuance of bi al-ma'tsur through the interpretation of the verse by verse, with the hadiths, and information from the companions. Also, what seems so thick in the interpretation of Sayyid Qutb's work is the style of al-adabi al-ijtima', especially in terms of deciphering the meaning and content of verses that have literary nuances with beautiful wording (adabi style), as well as its orientation to the social problems faced by the people (ijtima'i pattern) (Syafe'i, 2006). Even though in a methodological approach, from the literature found, this interpretation of al-adabi al-ijtima' does not have a clear and firm formulation, let alone a standard one (Syafe'i, 2006).

Talking about the congregation concept, what kind of model, form, or type of congregation concept can provide a unifying solution for the people and make it possible to apply in Indonesia? In this regard, the interpretation of Sayyid Qutb's work as a contemporary interpretation can adequately represent the congregation concept in the contemporary context. His interpretive thoughts made in the era of fifties, with his broad, deep, and far-sighted thoughts, are still very possible to be adapted and implemented in the current era (2011). Moreover, Tafsir Fî Zhilâl Al Qur'ân is the only tafsir haraki model that exists to date, namely the interpretation that discusses and examines the congregation concept as a forum for Islamic da'wah movement in upholding Islamic sharia.

The existence of a "sharp" controversy among scholars and Muslims regarding the congregation concept itself is another interesting aspect to be researched and to find out the correct answer. Some scholars and people think that the congregation is just a collection of individuals, social, and emotional Muslims only, either in the recitation congregation or 
mosque congregation, or just a collection of organizations, such as the Muhammadiyah, Persis, and NU congregations, or just prayer congregations in the prayer room and mosque. However, some people and other scholars consider that the congregation is a bond of Aqedah (not just a social and emotional bond), and this is something that is of a principle. In fact, the most extreme view states that whoever is not in the congregation, then their death is the death of ignorance (jahiliyah).

Research on the concept of leadership according to Sayyid Qutb has been done by many other researchers, including: Zabidi (2017) said that the urgency of leadership is important to understand and actualize in people's lives, this is due to seeing various phenomena that occur in society in everyday life which always clash with applicable rules or norms and laws. So we need an attitude of tolerance in dealing with problems that occur in society, including the problem of understanding the urgency of leadership. Yudha (2017) concludes several points about the principles of leadership, namely: First, the principles of leadership according to Sayyid Qutb which are contained in the Koran and deserve to be owned by a leader are; First, the leader must be a believer with the conditions of faith. Second, able to analyze problems, able to make decisions. Knowledgeable. Third, fair. Fourth, have the power, to guard the area of his leadership. Fifth, have sensitivity to problems, awareness. Sixth, responsibility, patience, trust. Seventh, free or not slave. Eighth, descendants of Quraysh. Second, the principles of leadership according to the scholars are; first, fair. second, knowledgeable. Third, healthy body or strong. Fourth, be insightful. Fifth, be brave. Sixth, the descendants of Quraysh. Seventh, baliqh. Eighth, men. Third, the opinions of Sayyid Qutb and the scholars have similarities. The outline is; First, fair. Second, knowledgeable. Third, strong or healthy body. Fourth, the descendants of the Quraysh.

Another study concluded that the analysis of the concept of leadership in the perspective of Sayyid Qutbh which is contextualized within the Indonesian state is considered irrelevant, because Indonesia's background has various cultures, ethnicities, and religions. In addition, if the Indonesian state already has an ideology to serve as the basis for carrying out its leadership, namely Pancasila. The values contained in Pancasila if understood in depth, do not conflict with Islamic values, including the principles of leadership according to Sayyid Qutb. Therefore, the State of Indonesia is appropriate if it is used as a source to carry out the wheels of leadership in Indonesia (Muhammad Sibro Malisi, 2017). Elha (2015) discusses more deeply about many things related to the leadership of Hamka's study of thought. The discussion in it contains about understanding the verses about 
leadership in the interpretation of his work. Also discussing the terms or meanings that have been used by Hamka in explaining the purpose of leadership itself. Sayyid Qutb's thoughts are considered influential in the Islamic world. Ritajuddiroyah (2016) said that Sayyid Qutb raised the awareness of the Muslims towards their oppression of the West and their rejection of modernization, secularization and westernization which he considered modern ignorance. In fact, tolerance is part of the theological vision or Islamic faith. The framework of the Islamic theological system should be studied in depth and applied in religious life. Peneliti terakhir, Habibie (2017) found that in general the interpretations of Al-Mishbah and Fi zilal al-qur'an both interpreted the leader as identical with the term; caliph, uli al-amri, imam and malik. Then they also agreed that men are more entitled to be leaders than women based on the specificity and nature of each, because of the heavy duty and responsibility of this leadership.

The research above suggests discussing leadership in general, tolerance, politics, gender, state ideology, without touching aspects of educational leadership based on the concepts of unity and unity. Thus, this research is important to complete the concept of leadership from an educational perspective according to Sayyid Qutb.

Are the verses and hadiths about the congregation revealed in the Arab region with the socio-culture and conditions that existed at that time to be relevant to Indonesian and current conditions? It is where it gets interesting. How can a Sayyid Qutb, with his contemporary interpretation, explain and perceive the congregation concept in actual, factual, and answerable contextual phenomena that exist today? It will also be something interesting to study. Thus, the research problem formulation is: How is the interpretation of the congregation concept according to Sayyid Qutb in Tafsir Fî Zhilâl al-Qur'ân?

This research's implication is that revealing congregation concept through the interpretation of the Al-Qur'an, which is then analyzed in-depth and objectively, will give birth to an understanding of the congregation correctly and precisely, which can be applied in current conditions, especially in Indonesia.

In his book entitled "Sayyid Qutb: Khulâshatuhu wa Manhâju Harakâtihi", Muhammad Taufiq Barakat divides Sayyid Qutb's thought phases into three stages: the stage of thinking before having an Islamic orientation, the stage of having an Islamic orientation in general, and the stage of thinking oriented towards militant Islam.

During this third phase, Sayyid Qutb began to feel an aversion and disgust towards westernization, colonialism, and the Egyptian rulers. It was this period that made him active 
in fighting for Islam and rejecting all forms of westernization, which, at that time, was often heralded by other Islamic thinkers who were dazzled by the glories of Western cultures (Mujahidin, 2011).

In his view, Islam is a manhaj Ilahi made to (govern) humans who live on this earth. Islam is also a perfect way of life. Islam is the spirit of life that regulates and provides solutions to social problems. Al-Qur'an in the order of Muslims is considered the first reference in making laws and regulating the community lifestyle because it is considered the main principle in Islam. Thus, Al-Qur'an must solve the existing problems. Based on this assumption, Sayyid Qutb tried to take a new approach in interpreting the verses of the AlQur`an to answer all kinds of problems. His very basic thought is the necessity to return to Allah and to the order of life that He has described in Al-Qur`an if humans want happiness, prosperity, harmony, and justice in navigating the life of this world. Concretely, Al-Qur'an must be made a book that regulates life and law in all matters if the life of this world is to be in harmony (Quthb, 2007).

Al-Qur'an is the final and perfect samawat book, in which it describes the phenomena that occurred at the time of the Prophet and the stories of the past. It is undeniable, even though the Al-Qur'an was passed down 14 centuries ago, its values, essence, rules, and Sharia laws are still relevant and always in line with the existing developments. Hence, it is not wrong if the events of the passing down of Al-Qur'an are considered a blueprint for humankind's history in the next phase. Also, it is not surprising that the interpretations that have been attempted by classical scholars need to be readjusted in the present. Departing from that, Sayyid Qutb tried to make a new breakthrough in interpreting the Al-Qur'an, which departed from the social realities and then rectified what is considered untrue that happens in that reality. Therefore, in his interpretation, Sayyid Qutb did not mention what most of the mufasir discussed, such as the Al-Qur'an in terms of language, knowledge of kalam, the science of fiqh, or other temporal subjects (Quthb, 1983). Apart from that, a breakthrough in Sayyid Qutb's interpretation was also to reveal the Al-Qur'an in terms of the beauty of Al-Qur'an art, which has an extraordinary uslub (expression) arrangement (Quthb, 1983).

Tafsir Fî Zhilâl al-Qur'ân was written by Sayyid Qutb while he was in prison. Qutb was locked up in a small 1 cell with forty other people who were mostly criminals. Sayyid Qutb was also subjected to tremendous physical torture and mental stress every day. One 
from of mental stress experienced was listening to the President's lectures twenty hours a day. It was also experienced by other activists of Ikhwan al-Muslimin. It was in such conditions that Tafsir Fî Zhilâl al-Qur'ân was born (Nurdi, n.d).

\section{Tafsir Fî Zhilâl al-Qur'ân Book}

Tafsir Fî Zhilâl al-Qur'ân is a six-volume book of contemporary interpretations by Sayyid Qutb published by Dar al-Syurûq, Beirut. It has been reprinted several times in just a few years and translated into various languages because this spectacular interpretation has received a warm welcome from educated people and inspiring and making a deep impression on Muslims' hearts.

The writing of Tafsir Fî Zhilâl al-Qur'an was completed by Sayyid Qutb in prison between 1952 and 1954 as many as 18 juz. After he was released in March 1954, he was again imprisoned in November of the same year. Writing Tafsir Fî Zhilâl al-Qur'an stopped because of the various tortures he experienced in prison. However, thanks to the publisher's services, he could gradually complete the interpretation writing and revise the previous juz (Hidayat, n.d).

\section{The Essence of Tafsir Fî Zhilâl al-Qur'ân}

Tafsir Fî Zhilâl al-Qur'ân is a haraki (movement: Islamic harakah) interpretation, which contains much social criticism, political movements, da'wah movements, jihad fi sabilillah movements, morality movements, ubudiyah worship movements, and ideology of Aqedah Islamiyah. This interpretation describes and elaborates how the kafir living system's characteristics developed and dominated all aspects of life (Rinto et al., 2020). From the issue of Aqedah, worship, moral behavior, household, lifestyle, social-community life (Karim et al., 2017), law, legislation to the governmental system, all have left the Islamic system and are in a state of ignorance, which is full of depravity, darkness, and humiliation. Thus, shirk/idolatry's aspect manifests in various forms of "countering" to Allah, from traditional to modern forms. Also, it starts from the match against His Essence, His system of worship, traditions and culture, His laws and regulations, to the match against the institution of governmental authority (state). Also, all of them are forms of idolatry as 
unpardonable, lowly, and despicable sins. As a result, various forms of disobedience, torment, oppression, greed, injustice, error, destruction, and various other misdeeds have emerged.

Seeing this reality, Islam has come to provide solutions and bring a shade of light, a shade of wisdom, a shade of peace, justice protection, and welfare protection through the rules it passed down, namely the Al-Qur'an. Thus, various parties are called upon to adhere to the Al-Qur'an, follow the Al-Qur'an's instructions, and obey the rules, laws, orders, and prohibitions contained in the verses of the Al-Qur'an. Besides, the Al-Qur'an is a perfect rule and system, as the One who makes it, namely Allah is Perfect. Meanwhile, the rules, systems, or laws made by humans are fragile and imperfect, just like what makes them, namely humans who were created by Allah in a state of not being perfect. Hence, imperfect conditions, systems, or laws will cause various harm, as mentioned above. Thus, in all aspects of life are under the auspices of Al-Qur'an (Fî Zhilâl al-Qur'an), it means that the individual, family, community, and state are under the auspices of the rules and laws of AlQur'an, namely as perfect rules. Then, it will all have an impact on the benefit as mentioned above as well.

In conclusion, the Al-Qur'an must be upheld, preached, and fought for to the very last drop of blood so that it (with the complementary of the Al-Sunah) becomes the only personality character, the only foundation of ubudiyah worship, the only lifestyle, the only rule, law and legislation, and the only system of government. Therefore, this is monotheism (the opposite of polytheism), faith (the opposite of disbelief), and al-Haq or truth (the opposite of al-Bathil or error). It needs to be realized to achieve harmony, peace, congruence, balance, justice and welfare of all parties, both for believers, non-believers, animals, environment (Karim et al., 2020), plants, and the universe. Such is the description of the contents of Tafsir Fî Zhilâl al-Qur'an, summarized in the Essence of Tafsir Fî Zhilâl alQur'an (Quthb, 2007).

\section{Research Method}

The methods used in this research discussion were library research and content analysis. The library research method was carried out by examining books and writings related to the problem under study and in accordance with the object under study (Meleong, 2008), or a method with a literature study approach. In this case, the problem and object under study was the congregation concept. Meanwhile, the content analysis method is a 
research method that utilizes a set of procedures to draw valid conclusions from a document or message carried out objectively and systematically (Meleong, 2008).

The type of data is the amount of data needed in making this research. This type of data consisted of qualitative data related to the problem under study. These data were taken from various literature in the form of books (kitab), books, and information obtained from various sources. The data collected were sorted and selected which parts could be used as a source of reference or a scientific basis to discuss the problem being studied.

The data source is the source from which research data is collected. Data sources are divided into two parts: primary data sources and secondary data sources. The primary data source is the person who is the information source, in this case, Sayyid Qutb. Meanwhile, secondary data sources consist of primary-secondary data sources, which become core data and supporting secondary sources, which become complementary data.

The data collection technique is a way of collecting the necessary data in accordance with the object under study. In another sense, it is a description of the primary data collection techniques employed in accordance with the object being studied. In this study, the data collection technique was to study and examine various library materials, which consisted of literature as data sources. Techniques like this are called documentation studies or literature studies because they collect various sources of literature in the form of secondary sources (Suhartono, 2001).

The collected data were then grouped based on the structure of the problem discussion for further study, analysis, and comparison according to the required portion, capacity, and level. In data analysis, data were detailed, classified, and interpreted and criticized to obtain a correct and objective conclusion.

\section{Research Finding}

\section{Definition of Jamaah (Congregation)}

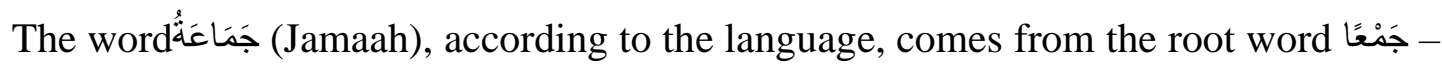
يَجْمَعُ - جَمَعَ , which means to collect, put together, add up, compile/quote from another book, plural (Munawir, 1984). Jamaah also means group (Ali \& Muhdlor, 1998). Some interpret jamaah as a collection (Mandzur, 1972). Meanwhile, in the book Al Mu'jam al Wasîth, jamaah means a group of people (MLA, 2004). Besides, in the book al Mu'jam al-Wajîz, jamaah is defined as a group of people with one or the same goal (MLA, 2004). 
The development of the word jamaah, which means to collect, has various meanings to be al-jam'u (collection), al-ijma' (agreement), and al-ijtima' (association). The opposite (antonym) of jamaah is al-Tafarruq, which means division. Ibn Faris said: "Jim, Mim, and A'in are one basis that shows the gathering of something. It says jama'tu asy-syai'a jam'an (I collect something) (Ismail, 2011).

According to the sharia view, jamaah is a prayer congregation, a group of people, an association of Muslims in a particular business, and a group of people who adhere to the Prophet Muhammad and his companions' teachings. From several meanings above, the most appropriate sharia definition is the last (RoL, 2007).

\section{Jamaah Definition in Tafsir Fî Zhilâl al-Qur'ân}

Tafsir Fî Zhilâl al-Qur'ân, as one of the existing contemporary interpretations, is an interpretation with a unique and different study from other interpretations. The book of Fî Zhilâl al-Qur'ân is indeed a book of interpretation with its own interpretation style and is a new breakthrough type of interpretation. However, in the elaboration of his interpretation, Sayyid Qutb indeed could not be separated from the approaches of the existing methods of the scholars' interpretation works. In general, the methods of interpretation used by scholars are the tahlili method (analysis), the ijmali method (global), the muqaran method (comparison), and the maudhu'i method (thematic) (Anwar, 2009); although not predominantly, some of them were also used by Sayyid Qutb.

Regarding the jamaah concept, which is this research's topic, to study the jamaah concept and see the jamaah phenomenon from the contemporary side, an accurate and representative data source is Tafsir Fî Zhilal al Qur'ân by Syekh Sayyid Qutb. It is because he is one of the contemporary ulama figures who intensively and specifically examined the congregation's problems. He was even directly involved in the congregation activities, in a harokah, Islamiyah Ikhwan al-Muslimin in Egypt, spearheaded by Hasan al-Banna (Quthb, 1985).

In terms of interpretation style, Tafsir Fî Zhilâl al-Qur'ân used the tashwir (descriptive) method. Observing the tashwîr method employed by Sayyid Qutb, primarily when he studied the congregation concept, it can be said that Tafsir Fî Zhilâl al-Qur'ân can be classified into the interpretation of al-Adabi al-Ijtimâ'i. It is an interpretation that seeks to reveal the beauty of the Al-Qur'an language and its miracles, explain its meaning, show the rules of Al-Qur'an about society, and solve problems of Muslims in particular, as well as various other problems 
in general (Anwar, 2009),such as the problem of compliance between leaders and societies (Karim et al., 2020). Therefore, the interpretation of al-Adabi al-Ijtimâ'i is also called a literary-cultural and social-oriented interpretation.

In view of his interpretation, Sayyid Qutb considered Islam a manhaj Ilahi made to (govern) humans who live on this earth. Islam is also a perfect way of life. Islam is the spirit of life that regulates and provides solutions to social problems. Al-Qur`an in the order of Muslims is considered the first reference in making laws and regulating the community lifestyle because it is considered the main principle in Islam. Thus, Al-Qur`an can solve the existing problems. Based on this assumption, Sayyid Qutb tried to take a new approach in interpreting the verses of the Al-Qur'an to answer all kinds of problems. His very primary thought is the necessity to return to Allah and to the order of life that He has described in Al-Qur`an if humans want happiness, prosperity, harmony, and justice in navigating the life of this world. Concretely, Al-Qur'an must be made a book that regulates life and law in all matters if the life of this world is to be in harmony (Quthb, 2007).

Al-Qur'an is the final and perfect samawat book, in which it describes the phenomena that occurred at the time of the Prophet and the stories of the past. It is undeniable, even though the Al-Qur'an was passed down 14 centuries ago, its values, essence, rules, and Sharia laws are still relevant and always in line with the existing developments. Hence, it is not wrong if the events of the passing down of Al-Qur'an are considered a blueprint for humankind's history in the next phase. Also, it is not surprising that the interpretations that have been attempted by classical scholars need to be readjusted in the present. Departing from that, Sayyid Qutb tried to make a new breakthrough in interpreting the Al-Qur`an, which departed from the social realities and then rectified what is considered untrue that happens in that reality. Therefore, in his interpretation, Sayyid Qutb did not mention what most of the mufasir discussed, such as the Al-Qur'an in terms of language, knowledge of kalam, the science of fiqh, or other temporal subjects (Quthb, 1983). Apart from that, a breakthrough in Sayyid Qutb's interpretation was also to reveal the Al-Qur'an in terms of the beauty of Al-Qur'an art, which has an extraordinary uslub (expression) arrangement (Quthb, 1983).

Through his interpretation's elaboration, Sayyid Qutb described how a congregation, according to Islamic views, how the congregation is actualized in an Islamic harokah movement, how the jamaah becomes essential and the principle aqidah risalah ilahiyah. In describing the congregation concept of various things studied, Sayyid Qutb almost always 
linked every sharia movement with the very thick dimensions of the afterlife and the soul. In his view, Al-Qur'an is very concerned about the scenes of the end: resurrection and reckoning, pleasure and torment. The afterlife dimension in spiritual view is alive and moving, real, concrete, clear, and bright (Quthb, 2006; Karim \& Hartati, 2020). The spiritual of leaders also can instilling the value of followers (Fikriyah et al., 2021). The scenes of the afterlife are seen by the eye and felt by the taste. Also, the congregation concept is a Sharia concept that is also closely related to the afterlife dimension (Quthb, 2006).

\section{Jamaah As One Leadership Unit}

The Jamaah as an institutional unit, of course, will give birth to a consequence, in which the congregation must automatically be under one leadership unit. Leadership is a symbol of the institution itself. Besides, Islam is al-Dîn, which introduces and requires the existence of this leadership system.

Umar bin Khaththab in a statement said:

Having told us Yazid bin Harun, had told us Baqiyyah, had told me Shafwan bin Rustum from Abdur Rahman bin Maisarah from Tamim Ad radliallahu 'anhu, he said: "People were competing to raise buildings in Umar's era, then Umar said: "O Arab people, remember, remember, in fact, there is no Islam except in congregation, and there is no congregation except with leadership, and there is no (point of) leadership except by obedience. Whoever is respected by his people because of knowledge, it will bring goodness to his life and society, and whoever is respected by his people, not because of knowledge, is destroyed (as well as) his people " (al-Dârimi, n.d).

Umar bin Khaththab's statement said:

Remember, in fact, there is no Islam except with congregation, and there is no congregation except with leadership, and there is no (point) leadership except by obedience.

It is a signal that Islam must be an institution in the form of a congregation, and the congregation which is an Islamic institution must have leadership. Meanwhile, a leader must be followed by obedience. If not, it will be useless to have institutions and leaders, but they are disobeyed, loyal, and supported by their members or the people.

Concerning leadership as one unit in the congregation, Sayyid Qutb in the Tafsir Fî Zhilâl al-Qur'an discusses Surah Al-Nisa [4] verse 59, which means as follows: 
O believers! Obey Allah and obey the Messenger and those in authority among you. Should you disagree on anything, then refer it to Allah and His Messenger, if you 'truly' believe in Allah and the Last Day. This is the best and fairest resolution.

In this verse, Allah explains the requirements of faith and the limits of Islam. Along with that, the basic rules of nizham (basic regulations) for Muslims, legal principles, and power sources are explained. In fact, the rule of law belongs only to Allah, for humans, both in big and small matters, Allah has made the Sharia as outlined in the Al-Qur'an, also by sending messengers who obey Allah and do not walk with their passions. Therefore, Rasul's Sharia is Allah's Sharia.

The condition for faith is obeying Allah by carrying out His provisions and obeying the Messenger by carrying out the Sharia, which one actualizes in translating God's message. The implementation of this Sharia indicates a condition of faith and the limits of Islam for a person (Quthb, 2006).

However, it is not enough. There is the next condition of faith, namely obeying Ulî alAmri (leader) followed by the word مِنٌْ (among you). It means that the leader of the believers themselves, where they have met the requirements of the faith and the limits of the previous faith, namely Ulî al-Amri, who obeyed Allah, His Messenger, and the Sharia established. Thus, only among the believers who affirm Allah as the owner of the rule of law and the right to make Sharia for all humans. Also, for those who accept the law that comes from Allah and return to Allah, all matters disputed by the human mind through the texts that $\mathrm{He}$ revealed to be the source of all law sources are this believer's characteristic deserves to be obeyed as a leader.

Therefore, in the lafadz verse, the words Allah and Rasul are followed by the word أَطِعُوا Allah and Rasul is absolute, while obedience to Ulî al-Amri is conditional. It is as long as Ulî al-Amri obeys Allah and His Messenger and observes the Sharia prescribed by both, and carrying out the provisions of this rule is a characteristic of someone who believes in Allah and yaumil akhir (Quthb, 2006).

Method of interpretation: Qutb interpreted this verse with the tahlili method, which describes the verses based on their reasoning by interpreting verse by verse and munasabah. In his approach, Qutb performed tashwir (descriptive) with al-Adabi al-Ijtimâ'i (literature, culture, society, and overcoming people's problems) by observing the situation and conditions in society. Qutb brought the understanding that the space of faith for a believer is 
in obedience to the congregation's structure, namely through obedience to Allah, the Prophet, to Ulî al-Amri (leader/imam for the Muslims) who leads the Muslim congregation (as long as the leader obeys Allah and His Apostle). In this case, Qutb tried to direct that there must be leadership in Islam, and it is absolute. It is because making leadership and obeying that leadership indicates one's faith in Allah and the hereafter. Thus, Qutb tried to link that building leadership in Islam is closely related to the afterlife phenomenon. It is because whether a person's walla leadership is right in the world will impact his fate in the hereafter. This view is in line with the historical situation and conditions of leadership in Egypt and leadership competition in the world, leading to the liberalist bloc and the communist bloc and the phenomenon of colonial leadership. This leadership condition gives birth to an arbitrary, authoritarian, and more indulgent attitude. Thus, Qutb thought that Muslims should return to the leadership that Allah and His Messenger had proclaimed.

Regarding obedience to leaders, the Prophet said:

Has told us Muhammad bin Basysyar, has told us Ghundar, has told us Syu'bah from Zubaid from Sa'd bin Ubaidah from Abu 'Abdurrahman from' Ali radliallahu 'anhu that the Prophet sallallaahu' alaihi wasallam had sent an army and raised someone as their amir. The Amir then lit a fire and gave the order, 'Enter you into this fire!' Some of them wanted to enter it and some said, 'Do not we ourselves want to escape from the fire (of hell)?' Finally, they reported the case to the Prophet sallallaahu 'alaihi wasallam and he said to those who wanted to enter it: "If they enter it, they will certainly remain in that fire until the end comes." And he said to others: "There is absolutely no obedience in wickedness; obedience is in goodness."

The hadith part states:

There is absolutely no obedience in wickedness; obedience is in goodness.

The leadership problem is an issue related to the principle of Al-Walla (loyalty) in Islamic teachings. Thus, as long as a leader falls within the criteria of faith as described above, there is no reason for people to leave obedience to that leader.

In verse, Allah says which means the following:

Your only guardians are Allah, His Messenger, and fellow believers-who establish prayer and pay alms-tax with humility (QS. Al-Maidah [5]: 55).

According to Sayyid Qutb's interpretation, this verse deals with the limitation of believers' loyalty according to faith's nature. It is a matter of Aqedah and a problem of the Aqedah movement. The aim is that the believers' loyalty is only for Allah sincerely so that 
Islam is made as "Dîn" (the institutional treatise that upholds the Islamic system). It is also a matter of affirming the separation between the ranks of believers and those that do not make Islam a "Dîn" and a manhaj in their lives. Thus, loyalty should not be given to other than one leader and one flag. It is also so that believers help each other because helping is a matter of manhaj originating in Aqedah (Quthb, 2006).

Method of Interpretation: Qutb brought the understanding of this verse to the realm of ideology and the principles of Islamic Aqedah. In his analysis (tahlili), through ijtihad, Qutb described part by part of the verse profoundly and firmly. The phenomenon of tashwir (descriptive) in the approach of al-Adabi al-Ijtimâ'i (literature, culture, society, and overcoming the people' problems) is also very thick because Qutbh interpreted this verse by looking at the reality of Egyptian society and the world at that time, which tended to be loyal to Western thought, ideology, and leadership.

Thus, Allah, Rasul, and the believers are a united congregation's structure, which in turn, is actualized through a unity of leadership and a flag (institutional) in which the Islamic ummah helps each other in fighting for God's message.

Moreover, the issue of loyalty to a leader is crucial to the point that the Prophet in his words emphasized obedience to the leader even though the leader has shortcomings and weaknesses. In his words, the Prophet said:

Having told us Muhammad bin Al Mutsanna and Muhammad bin Basyar, both said; has told us Muhammad bin Ja'far, has told us Syu'bah from Simak bin Harb from 'Alqamah bin Al Wa`il Al Hadlrami from his father, he said, "Salamah bin Yazid Al Ja'fi once asked Rasulullah sallallaahu. 'Alaihi wasallam, "O Prophet of Allah, what do you think if the rulers who lead us always claim their rights over us, but they do not want to fulfill our rights; what attitude do you suggest to us?" So, he turned away, then asked him again, and he was still reluctant to answer it until two or three times the question was asked to him. Then, Al Aty'ats bin Qa'is pulled Salamah bin Zayid. He then said: "Listen and be obedient, in fact, they will be responsible for all their actions, as you will also be responsible for all your actions." Having told us Abu Bakr bin Abu Syaibah, had told us the Syababah had told us the Syu'bah of Simak in this manner, he said, "Then, Al Asy'ats bin Qa' is pulled Usama bin Zayid, then he replied:" Listen and obey, in fact, they will be responsible for all their actions, as you will also be responsible for all your actions." (Muslim, n.d)

From the hadith information, it is clear that obedience to a leader is principle even though some mistakes are made. 
Apart from that, the Prophet also indicated that leadership in Islam must be one, and there should not be dualism of leadership. Therefore, the Muslim community is an institution within one leadership unit. The Prophet said:

And having told me Wahb bin Baqiyah Al Wasithi, told us Khalid bin Abdullah from Al Jurairi from Abu Nadlrah from Abu Sa'id Al Khudri, he said, "Rasulullah sallallahu 'alaihi wasallam said:" If there are two caliphs who are enshrined, then kill the last of the two." (Muslim, n.d)

Not allowed if there are two caliphs (leaders) in power. It indicates that Islam requires a unity of leadership so that Muslims are in unity. Thus, it must be ensured that every Muslim must have a leader and be under one community leadership. In a hadith, the Prophet said:

Having told us Aswad bin 'Amir had told us Abu Bakr from' Asim from Abu Salih from Mu'awiyah said; Rasulullah Sallallahu'alaihiwasallam said: "Whoever dies without having an Imam, he will die like the Jahiliyah." (Ahmad, 1990).

It is a clear picture that Muslims must take the form of a leadership unit within a congregational institution. If not, there will be quite severe consequences, namely falling into the status of polytheism, and his death is categorized as Jahiliyah.

\section{Conclusion}

According to Sayyid Qutb in Tafsir Fî Zhilâl al-Qur'ân, the meaning of the congregation is a system of the unity of Islamic society, coordinated in the unity of Aqedah, leadership, rules/laws, institutions, behavior (Akhlaq), ummah, who make efforts to struggle and movement until the establishment of Daulah Islamiyah in the form of an Islamic state or government. Until in the end, Islam becomes the only manhaj (system), rules, and laws that apply on this earth with the caliphate establishment, which shelters the lives of humans, believers and non-believers, the environment, and the various lives around it with just, peaceful, full of compassion, harmony, and benefit as the embodiment of Islam rahmatan lil'alamîn. According to Qutb, the congregation phenomenon is not only an obligation for Muslims to uphold it in the world but also something that will have an impact and determine a person's fate in the hereafter. In the afterlife, humans will be gathered based on their leadership, the manhaj (system) they embrace, and the institutions (congregations) or flags that shelter them. 


\section{Bibliography}

Ahmad,Musnad.Kitab: Musnad al-Syâmiyyîn. Mesir: Kutubu Tis’ah, 1990.

Aji, T. S., Karim, A., Hori, M., Maryati, S., Nurkholis, Sudin, M., Surono, Jakaria, Irfan, A., \& Nurjannah, W. (2020). The Concept of Togetherness and its Implications for the Unity of the Society: Study of Elucidation by Quthb. International Journal of Psychosocial Rehabilitation, 24(08), 13800-13808. https://doi.org/10.37200/IJPR/V24I8/PR28136.

Al-Dzahabi,Muhammad Husain.Al-Tafsir wa al-Mufassirûn. al-Mujallad al-Awwal, 1976.

Ali,Atabik \&Muhdlor,Ahmad Zuhdi.Kamus Kontemporer. Yogyakarta: Multi Karya Grafika, 1998.

Al-Zarkasyi.Al-Burhân Fî Ulûm al-Qur'ân. Jld. 2. Mesir: Isa al-Bab al-Halabi, 1972.

Anwar,Rosihon.Menelusuri Ruang Batin al-Qur'ân. Bandung: Erlangga, 2010.

Anwar,Rosihon.Pengantar Ulumul Qur'an. Bandung: Putaka Setia, 2009.

Calvert, John. "The World is an Undutiful Boy: Sayyid Qutb's American Experience." Islam and Christian-Muslim Relations, vol. II, no.1 (2000): pp. 87-103.

Elha, A. M. S. (2015). Penafsiran Hamka tentang Kepemimpinan dalam Tafsîr Al Azhâr. Universitas Islam Negeri Walisongo.

Fikriyah, Karim, A., Huda, M. K., \& Sumiati, A. (2021). Spiritual leadership: The case of instilling values in students through the Kiai's program in the globalization era. Journal of Leadership in Organizations, 3(1), 16-30. https://doi.org/https://doi.org/10.22146/jlo.63922.

Habibie, M. (2017). Konsep Kepemimpinan menurut Tafsir fi Zhilal Al-Qur'an dan AlMishbab. Institut Agama Islam Negeri Raden Intan Lampung.

Hanafi, Y., Taufiq, A., Saefi, M., Ikhsan, M. A., Diyana, T. N., Hadiyanto, A., ... \& Mawardi, A. I. (2020). Indonesian ulema council fatwa on religious practices during Covid-19 pandemic: An investigation of Muslim compliance.

Indriyanti, T., Siregar, K. I., \& Lubis, Z. (2015). Etika interaksi guru dan murid menurut perspektif Imam Al Ghazali. Jurnal Studi Al-Qur'an, 11(2), 129-144.

Jabir,Hussain bin Muhammad bin Ali.Al-Tharîq Ilâ Jamâ 'ati al-Muslimîn.Kairo: Dâr alWafa, 1990.

Karim, A., Faiz, A., Parhan, M., Gumelar, A., Kurniawaty, I., Gunawan, I., Wahyudi, A. V., \& Suanah, A. (2020). Managerial leadership in green living pharmacy activities for the development of students ' environmental care in elementary schools. 
Journal of Critical Reviews, 7(13), 714-719 http://www.jcreview.com/?mno=11912

Karim, A., \& Hartati, W. (2020). Spiritual tasks of teachers in higher order thinking skillsoriented learning. International Journal of Psychosocial Rehabilitation, 24(8), 4568-4580. https://doi.org/10.37200/IJPR/V24I8/PR280474.

Karim, A., Purnomo, H., Fikriyah, F., \& Kardiyati, E. N. (2020). A charismatic relationship: How a Kyai's charismatic leadership and society's compliance are constructed? Journal of Indonesian Economy and Business, 35(2), 129-143. https://doi.org/https://doi.org/10.22146/jieb.54705

Karim, A., Mardhotillah, N. F., \& Rochmah, E. (2017). Dampak kharisma kyai terhadap miliu kesalehan sosial. Seminar Nasional Hasil Penelitian Universitas Kanjuruhan Malang 2017, 1-5.

https://semnas.unikama.ac.id/lppm/prosiding/2017/4.Pendidikan/1.AbdulKarim_Nu r_Fitri_Mardhotillah_Eliya.

Kepel, Gilles. The Prophet and Pharaoh: Muslim Extremism in Egypt,Al Saqi, 1985.

Majma' al Lughat al Arabiyyah.Al Mu'jam al Wasith. Kairo: Maktabah al-Syuruq al Dauliyah, 2004.

Muhammad Sibro Malisi. (2017). Konsep Kepemimpinan menurut Sayyid quț dalam Tafsir fì Zilāl Al - Qur'ān. Universitas Islam Negeri Sunan Kalijaga, Yogyakarta.

Mandzur,Ibn.Lisânu al-Arabi. Kairo: Dar al-Ma'arif, 1972.

Mannâ' al-Qaththân.Mabâhis fì 'Ulûm al-Qurân. Riyadh: Mansyurat al 'Asr al-Hadist, 1973.

Moleong,Lexy J. Metode Penelitian Kualitatif. Bandung: Remaja Rosadakarya, 2008.

Munawwir,Ahmad Warson.Kamus Al Munawwir. Yogyakarta: Unit Pengadaan Buku Ilmiah Keagamaan Ponpes Al Munawwir, 1984.

Qodriah, S. L., Hartati, W., \& Karim, A. (2019). Self-leadership and career success: Motivation of college lecturers. Journal of Leadership in Organizations, 1(2), 7995. https://doi.org/https://doi.org/10.22146/jlo.47772

Quthb,Sayyid.Al-Tashwir al-Fannî fî al-Qur'ân. Beirut: Dar al-Syurûq, 1983.

Quthb,Sayyid.Masyâhid al-Qiyâmah fì al-Qur'ân. Beirut: Dar al-Syurûk, 2006.

Quthb, Sayyid. Mu'âlim fî al-Tharîq. Beirut: Dar al-Syurûq, 1992.

Quthb,Sayyid.Tafsir Fî Zhilâl al- Qur'ân. Beirut: Dar al-Syurûq, 2007.

Rinto, Fikriyah, Iman,B. N., Hanikah, Munajim, Ahmad,S., Setiana,D., Darmini,M., Karim, A. (2020). Scientific process skills learning, biotechnology materials, and 
character building, International Journal of Pharmaceutical Research, 12(4), 2044-2051. https://doi.org/10.31838/ijpr/2020.12.04.314.

Shahih Bukhari. Kitab: Akhbâru al-Âhâd. Mesir: Kutubu Tis'ah, t.th.

Shahih Muslim. Kitab: Al-Imârat [Kepemimpinan]. Mesir: Kutubu Tis'ah, t.th.

Shaleh,Ahmad Syukri.Metodologi Tafsir al-Qur'an Kotemporer dalam Pandangan Fazlu al-Rahman. Jambi: Sulthan Thaha Press, 2007.

Shawi, Shalah. Al-Tsawâbit wa al-Mutaghayîrat. Solo: Era Intermedia, 2002.

Suhartono,Irwan.Metode Penelitian Sosial. Bandung: Remaja Rosadakarya, 2001.

Sunan al-Dârimi.Kitab: Kitab Mukaddimah[Kitab Pendahuluan]. Mesir: Kutubu Tis'ah, t.th.

Syafe'i,Rahmat.Pengantar Ilmu Tafsir. Bandung: Pustaka Setia, 2006.

Ritajuddiroyah, A. (2016). Menemukan toleransi dalam tafsir fi zilal Al-Qur'an. Suhuf, 9(1), 190-191.

Yudha, E. M. (2017). Prinsip Kepemimpinan dalam Al-Quran menurut Sayyid Quthb (Studi Ayat-Ayat Prinsip Kepemimpinan dalam Tafsir Fi Zhilalil Quran). Universitas Islam Negeri. 
